\title{
Characteristics of Natric Troporthents Occurring in Semi-Arid Ecoregion of Rajasthan
}

\author{
Indra R. Singh ${ }^{1} \&$ P. R. Kameriya ${ }^{2}$ \\ ${ }^{1}$ College of Agriculture, Fisheries and Forestry, Fiji National University, Fiji \\ ${ }^{2}$ College of Agriculture, Rajasthan Agricultural University, Bikaner, 334 006, India \\ Correspondence: Indra R. Singh, College of Agriculture, Fisheries and Forestry, Koronivia, Fiji National \\ University, Fiji. E-mail: indra.singh@fnu.ac.fj
}

Received: April 16, $2012 \quad$ Accepted: May 3, $2012 \quad$ Online Published: July 11, 2012
doi:10.5539/jas.v4n8p112
URL: http://dx.doi.org/10.5539/jas.v4n8p112

\begin{abstract}
Six representative soil pedons were studied in Jaipur district of Rajasthan comprising part of hot semi-arid ecoregion. The soils although loamy sand in texture exhibited extreme degree of hardness and supported sparse vegetative cover. All pedons were non saline (ECe ranging from 1.32 to $1.82 \mathrm{dSm}^{-1}$ ) but distinctly alkali (pHs ranging from 8.4 to 9.8). The exchange complex was dominated by sodium and ESP varied from 30 to 70 , generally decreasing with depth. ECe exhibited slight increase with depth while, pHs did not exhibit any definite trend of variation. Among the soluble ions, sodium was most abundant, while among the anions soluble carbonates and bicarbonates were much in excess over chloride and sulphates considered together. All the soils were calcareous and illuviation of $\mathrm{CaCO}_{3}$ was apparent as its content increased with depth. The soils were typical alkali in nature and could be classified as Natric Troporthents. Hitherto such soils have not been reported among the inventory of salt affected soils in India.
\end{abstract}

Keywords: Natric Troporthents, hot semi-arid ecoregion, calcareous, ESP, alkali soils

\section{Intoduction}

In India, salt affected soils cover an area of 9.38 mha (GOI, 2000). These are broadly grouped in two categories viz., saline and alkali (Bhargava et al., 1976). Taking into consideration their geomorphic settings, nature of salts present and zone of salt accumulation Bhumbla (1975) identified six different kinds of salt-affected soils viz, alkali soils of Indo-Gangetic alluvial plain; saline soils; potentially saline soils; coastal saline soils; deltaic saline soils and saline acid sulphate soils. The alkali soils in the Indo-Gangetic plain have been reported to form in regions with $>650 \mathrm{~mm}$ annual rainfall (Bhargava et al., 1980) and occur extensively in the Indo- Gangetic alluvial plain in regions with more than $100 \mathrm{~cm}$ annual rainfall. Similarly saline soils occur not only in humid regions of the Sunderban delta and on the Malabar coast with more than 170 to $300 \mathrm{~cm}$ annual rainfall but also in the arid regions with less than $30 \mathrm{~cm}$ annual rainfall. Extensive regions with less than $50 \mathrm{~cm}$ annual rainfall largely encompass saline or potentially saline soils, the latter generally have subsurface salinity. Alkali soils were not predicted to occur in regions with less than $50 \mathrm{~cm}$ rainfall (Bhargava et al., 1980). The present investigation in central part of Rajasthan reports the occurrence of alkali soils in regions with less than $500 \mathrm{~mm}$ mean annual rainfall.

\section{Material and Methods}

The study area is located between $75^{\circ} 28^{\prime}$ and $75^{\circ} 43^{\prime} \mathrm{E}$ longitude and $26^{\circ} 06^{\prime}$ and $26^{\circ} 22^{\prime} \mathrm{N}$ latitude, 427 metres above mean sea level. There is no perennial river flowing through the area, but the seasonal river "Bandi" passes through it and drains the area. Maximum temperature ranges between $35{ }^{\circ} \mathrm{C}$ and $48{ }^{\circ} \mathrm{C}$.To demarcate areas of similar soils several auger holes and field checks were undertaken and the observations for color, texture, depth etc. were recorded as per Soil Survey Manual (1975). On the basis of observations six representative pedons occurring in Jaipur District of Rajasthan were studied and horizon samples collected before on set of monson (rainy season) in the summer months for laboratory characterization as per standard methods of soil sample collection. Morphology was recorded as per Soil Survey Manual (USDA, 1951). Standard analytical methods as described by Richards (1954) and Jackson (1957) were followed for measuring various soils attributes like $\mathrm{pH}$, $\mathrm{ECe}$, soluble cations and anions, CEC and exchangeable cations, organic carbon content and particle size composition. 


\section{Results and Discussion}

All the studied pedons exhibited distinctly alkali nature with pHs values ranging between 8.7 and 9.8 in surface horizons and between 8.4 and 9.8 within the profiles (Table 1). While pedons 2, 3, 5 and 6 exhibited decreasing trend of $\mathrm{pH}$ with depth, pedons 1 and 4 exhibited slight increase in $\mathrm{pH}$ below the surface, followed by decrease subsequently. The ECe values varied in narrow range of 1.32 and $1.82 \mathrm{dSm}^{-1}$ and generally remained higher in the substratum than in the surface horizons (Table 1). Sodium remained the dominant cation followed by calcium plus magnesium and potassium, while amongst the anions bicarbonates were followed by carbonates, chloride and sulphates. The sum of bicarbonates and carbonates was greater than that of chlorides and sulphates there by indicating the dominance of salts capable of alkaline hydrolysis, the main characteristic feature of alkali soils (Table 2) (Bhargava et al., 1976) Amongst the exchangeable cations Na was dominant, accordingly the ESP values ranged between 30 (pedon 2) and 70 (pedon 1) (Table 3). All the soils were coarse textured with textural class varying within the narrow range of sandy loam to loamy sand and showing almost uniform clay content within each profile. Organic carbon content of these soils were observed very low (Sharma et al., 2004), it varied between 0.03 and 0.14 per cent and showed gradual decrease with depth. The organic carbon content of these soils are mainly because of less and scanty rainfall in the area that results in poor fertility status of thee soils as wel. $\mathrm{CaCO}_{3}$ content showed increase with depth ranging between 2 and 9 per cent showing some illuviation of liberated lime.

Table 1. Physico-chemical characteristics of soils

\begin{tabular}{|c|c|c|c|c|c|c|c|c|}
\hline Depth (cm) & $\begin{array}{c}\mathrm{ECe} \\
\left(\mathrm{dSm}^{-1}\right)\end{array}$ & $\mathrm{pHs}$ & O.C. $(\%)$ & $\mathrm{CaCO}_{3}(\%)$ & Sand $(\%)$ & Silt (\%) & Clay $(\%)$ & $\begin{array}{c}\text { Textural } \\
\text { Class }\end{array}$ \\
\hline \multicolumn{9}{|c|}{ Pedon 1 Natric Troporthents } \\
\hline $0-20$ & 1.77 & 8.7 & 0.09 & 2.5 & 81.0 & 6.8 & 12.2 & 1s \\
\hline $20-50$ & 1.58 & 8.9 & 0.07 & 3.0 & 80.8 & 6.5 & 12.7 & ls \\
\hline $50-100$ & 1.69 & 8.8 & 0.07 & 3.5 & 81.8 & 5.7 & 12.5 & 1s \\
\hline $100-152$ & 1.79 & 8.6 & 0.06 & 4.0 & 82.2 & 5.1 & 12.7 & ls \\
\hline \multicolumn{9}{|c|}{ Pedon 2 Natric Troporthents } \\
\hline $0-24$ & 1.36 & 9.8 & 0.09 & 2.0 & 84.7 & 5.8 & 9.5 & ls \\
\hline $24-62$ & 1.47 & 9.6 & 0.05 & 3.5 & 84.4 & 5.7 & 9.9 & ls \\
\hline $62-90$ & 1.56 & 9.5 & 0.05 & 3.5 & 84.4 & 5.3 & 10.3 & ls \\
\hline $90-138$ & 1.62 & 8.9 & 0.03 & 4.0 & 82.0 & 5.8 & 12.2 & ls \\
\hline \multicolumn{9}{|c|}{ Pedon 3 Natric Troporthents } \\
\hline $0-30$ & 1.64 & 8.9 & 0.08 & 2.0 & 84.4 & 5.8 & 9.8 & ls \\
\hline $30-55$ & 1.75 & 8.7 & 0.07 & 2.0 & 84.3 & 5.6 & 10.1 & ls \\
\hline $55-105$ & 1.82 & 8.6 & 0.05 & 2.5 & 84.5 & 5.0 & 10.5 & ls \\
\hline $105-160$ & 1.81 & 8.6 & 0.04 & 3.5 & 81.5 & 5.9 & 12.6 & ls \\
\hline \multicolumn{9}{|c|}{ Pedon 4 Natric Troporthents } \\
\hline $0-27$ & 1.66 & 8.9 & 0.12 & 4.5 & 80.7 & 7.1 & 12.2 & ls \\
\hline $27-49$ & 1.64 & 9.7 & 0.09 & 5.5 & 80.5 & 6.3 & 13.2 & sl \\
\hline $49-83$ & 1.48 & 9.6 & 0.07 & 8.0 & 80.9 & 6.2 & 12.9 & ls \\
\hline $83-122$ & 1.58 & 9.3 & 0.05 & 8.0 & 81.1 & 5.8 & 13.1 & ls \\
\hline \multicolumn{9}{|c|}{ Pedon 5 Natric Troporthents } \\
\hline $0-30$ & 1.32 & 9.8 & 0.14 & 4.5 & 80.7 & 6.3 & 13.0 & ls \\
\hline $30-63$ & 1.46 & 9.6 & 0.08 & 5.5 & 81.1 & 5.7 & 13.2 & ls \\
\hline $63-94$ & 1.54 & 9.2 & 0.07 & 7.0 & 81.0 & 5.8 & 13.2 & ls \\
\hline $94-131$ & 1.56 & 9.0 & 0.06 & 9.0 & 80.7 & 5.7 & 13.7 & sl \\
\hline \multicolumn{9}{|c|}{ Pedon 6 Natric Troporthents } \\
\hline $0-23$ & 1.66 & 8.8 & 0.11 & 2.5 & 80.8 & 6.4 & 12.8 & ls \\
\hline $23-52$ & 1.72 & 8.7 & 0.08 & 4.5 & 81.3 & 5.8 & 12.9 & ls \\
\hline $52-88$ & 1.78 & 8.5 & 0.06 & 6.0 & 81.5 & 5.4 & 13.1 & ls \\
\hline $88-136$ & 1.82 & 8.4 & 0.05 & 6.5 & 82.7 & 5.3 & 12.0 & ls \\
\hline
\end{tabular}


Table 2. Composition of saturation extract $\left(\mathrm{meL}^{-1}\right)$

\begin{tabular}{lcccccccc}
\hline Depth $(\mathrm{cm})$ & $\mathrm{Ca}^{2+}+\mathrm{Mg}^{2+}$ & $\mathrm{Na}^{+}$ & $\mathrm{K}^{+}$ & $\mathrm{CO}_{3}^{2-}$ & $\mathrm{HCO}_{3}^{-}$ & $\mathrm{Cl}^{-}$ & $\mathrm{SO}_{4}^{2-}$ & $\mathrm{SAR}^{*}$ \\
\hline \multicolumn{6}{l}{ Pedon 1 Natric Troporthents } \\
$0-20$ & 0.9 & 15.8 & 0.6 & 4.5 & 6.4 & 3.9 & 2.6 & 23.55 \\
$20-50$ & 0.8 & 14.2 & 0.5 & 4.2 & 4.9 & 3.5 & 2.9 & 22.45 \\
$50-100$ & 1.2 & 15.1 & 0.4 & 4.4 & 5.8 & 3.8 & 2.8 & 19.49 \\
$100-152$ & 1.4 & 15.9 & 0.4 & 4.2 & 6.0 & 4.5 & 3.1 & 19.00
\end{tabular}

Pedon 2 Natric Troporthents

$\begin{array}{lllllllll}0-24 & 1.0 & 11.5 & 0.8 & 4.2 & 5.8 & 1.4 & 1.9 & 16.27 \\ 24-62 & 1.2 & 12.6 & 0.6 & 3.9 & 5.5 & 2.8 & 2.1 & 16.27 \\ 62-90 & 1.4 & 13.5 & 0.5 & 3.6 & 5.2 & 3.4 & 3.0 & 16.14 \\ 90-138 & 0.8 & 14.8 & 0.4 & 4.1 & 4.8 & 3.9 & 3.2 & 23.40\end{array}$

Pedon 3 Natric Troporthents

$\begin{array}{lllllllll}0-30 & 1.8 & 13.4 & 0.9 & 4.6 & 6.8 & 2.6 & 2.0 & 14.12 \\ 30-55 & 1.6 & 15.0 & 0.7 & 4.5 & 6.4 & 3.4 & 2.8 & 16.77 \\ 55-105 & 1.4 & 15.8 & 0.6 & 3.1 & 6.2 & 4.6 & 3.9 & 18.88 \\ 105-160 & 1.4 & 15.8 & 0.5 & 3.0 & 6.1 & 4.8 & 4.1 & 18.88\end{array}$

Pedon 4 Natric Troporthents

$\begin{array}{lllllllll}0-27 & 1.8 & 13.8 & 0.6 & 4.4 & 5.8 & 3.2 & 2.8 & 14.55 \\ 27-49 & 1.7 & 13.9 & 0.4 & 4.2 & 5.2 & 3.4 & 3.0 & 15.08 \\ 49-83 & 1.5 & 12.6 & 0.4 & 3.9 & 4.6 & 3.2 & 2.9 & 14.55 \\ 83-122 & 1.4 & 13.9 & 0.3 & 3.6 & 5.0 & 3.6 & 3.1 & 16.61\end{array}$

Pedon 5 Natric Troporthents

$\begin{array}{lllllllll}0-30 & 1.2 & 1.0 & 0.8 & 4.3 & 5.8 & 1.2 & 1.7 & 14.20 \\ 30-63 & 0.8 & 12.8 & 0.6 & 4.2 & 5.6 & 2.5 & 2.1 & 20.24 \\ 63-94 & 0.6 & 14.0 & 0.5 & 3.5 & 5.1 & 3.3 & 3.2 & 25.56 \\ 94-131 & 1.4 & 13.5 & 0.4 & 3.6 & 4.0 & 3.9 & 3.8 & 16.14\end{array}$

Pedon 6 Natric Troporthents

\begin{tabular}{lllllllll}
$0-23$ & 1.6 & 13.8 & 0.8 & 4.2 & 5.6 & 3.4 & 3.1 & 15.43 \\
$23-52$ & 1.6 & 14.7 & 0.7 & 4.5 & 6.2 & 3.3 & 3.0 & 16.43 \\
$52-88$ & 1.4 & 15.5 & 0.6 & 4.6 & 5.8 & 3.8 & 3.2 & 18.53 \\
$88-136$ & 1.4 & 15.9 & 0.5 & 4.1 & 5.8 & 4.1 & 3.9 & 19.00 \\
\hline
\end{tabular}

SAR* : Sodium Adsorption Ratio 
Table 3. CEC and exchangeable cations (c.mol (p+) $\mathrm{kg}^{-1}$ )

\begin{tabular}{lccccc}
\hline Depth (cm) & CEC & $\mathrm{Ca}^{2+}+\mathrm{Mg}^{2+}$ & $\mathrm{Na}^{+}$ & $\mathrm{K}^{+}$ & $\mathrm{ESP}^{*}$ \\
\hline \multicolumn{7}{l}{ Pedon 1 Natric Troporthents } \\
$0-20$ & 7.45 & 1.42 & 5.20 & 0.72 & 69.80 \\
$20-50$ & 6.30 & 1.52 & 4.16 & 0.48 & 66.03 \\
$50-100$ & 5.85 & 2.20 & 3.28 & 0.28 & 56.07 \\
$100-152$ & 5.70 & 2.56 & 2.90 & 0.24 & 50.88 \\
Pedon 2 Natric Troporthents & & & \\
$0-24$ & 6.15 & 1.82 & 3.65 & 0.60 & 59.35 \\
$24-62$ & 5.85 & 2.78 & 2.54 & 0.48 & 43.42 \\
$62-90$ & 6.35 & 3.96 & 2.10 & 0.24 & 33.07 \\
$90-138$ & 6.25 & 4.02 & 1.88 & 0.24 & 30.08
\end{tabular}

Pedon 3 Natric Troporthents

$\begin{array}{llllll}0-30 & 6.35 & 1.84 & 3.70 & 0.56 & 58.27 \\ 30-55 & 5.95 & 2.28 & 3.41 & 0.67 & 57.31 \\ 55-105 & 6.30 & 2.54 & 3.10 & 0.48 & 49.21 \\ 105-160 & 6.45 & 2.78 & 3.20 & 0.26 & 49.61\end{array}$

Pedon 4 Natric Troporthents

$\begin{array}{llllll}0-27 & 5.80 & 2.78 & 2.76 & 0.54 & 47.59 \\ 27-49 & 6.80 & 3.22 & 3.21 & 0.32 & 47.21 \\ 49-83 & 7.15 & 4.24 & 2.54 & 0.34 & 35.52 \\ 83-122 & 7.20 & 3.78 & 3.10 & 0.28 & 43.05\end{array}$

Pedon 5 Natric Troporthents

$\begin{array}{llllll}0-30 & 9.25 & 1.42 & 6.34 & 0.84 & 68.54 \\ 30-63 & 9.15 & 2.38 & 5.38 & 0.76 & 58.80 \\ 63-94 & 8.45 & 3.12 & 4.36 & 0.65 & 51.60 \\ 94-131 & 8.20 & 4.18 & 3.30 & 0.54 & 40.24\end{array}$

Pedon 6 Natric Troporthents

\begin{tabular}{llllll}
$0-23$ & 5.85 & 1.72 & 3.48 & 0.64 & 59.49 \\
$23-52$ & 5.90 & 1.98 & 3.41 & 0.48 & 57.79 \\
$52-88$ & 6.80 & 3.10 & 3.36 & 0.28 & 49.41 \\
$88-136$ & 6.90 & 3.28 & 3.40 & 0.20 & 49.28 \\
\hline
\end{tabular}

ESP* : Exchangeable Sodium Percentage 
The soils in question lacked an illuvial clay rich B horizon in contrast to the alkali soils of higher rainfall regions but at the same time exhibited all other chemical attributes of alkali soils. Although they broadly represent Troporthents because of their loamy (loamy sand texture) and ECe of the saturation extract remaining less than 2 $\mathrm{dSm}^{-1}$ in all the horizons. But there is no provision in entisols for placement of soils with high ESP. In the present instance the soils have ESP values ranging between 30 and 70 therfore their logical class shall be Natric Troporthents as all of them have ESP more than 30 (Richards, 1954). Thus a new taxonomic class Natric Troporthents needs to be added within the Soil Taxonomy to accommodate such alkali soils occurring in arid / semi arid regions else where.

\section{References}

Anonymous. (2000). Indian Agriculture in Brief, Ministry of Agriculture, Government of India, New Delhi.

Bhargava, G. P., Abrol, I. P., \& Bhumbla, D. R. (1976). Nomenclature of some salt affected soils in Indo-Gangetic plains. Journal of the Indian Society of Soil Science, 24, 81-83.

Bhargava, G. P., Sharma, R. C., Pal, D. K., \& Abrol, I. P. (1980). A case study of the distribution and formation of salt affected soils in Haryana state. Internarional Symposium on Salt Affected Soils, Central Soil Salinity Research Institute, Karnal, India, pp. 83-91.

Bhumbla, D. R. (1975). Map of India, Salt Affected Soils, Central Soil Salinity Research Institute, Karnal, India.

Jackson, M. L. (1973). Soil chemical analysis. Prentice Hall of India (P) Ltd., New Delhi.

Richards, L. A. (1954). Diagnosis and improvement of saline-alkali soils. USDA Handbook No. 60 U. S. Department of Agriculture. Washington, D.C. (USA).

Sharma, S. S, Totawat, K. L., \& Shyampura, R. L. (2001). Characterization and classification of salt-affected soils of Southern Rajasthan. J. Indian Soc. Soil Sci., 52(3), 209-214

Soil Survey Staff. (1951). Soil Survey Manual. United States Department of Agriculture. U. S. Govt. Printing Office, Washington, D.C.

Soil Survey Staff. (1995). Soil survey manual. USDA, Scientific Publishers, Jodhpur India. 